\title{
CHEMICAL COMPOSITION, SENSORY AND MICROBIAL ATTRIBUTES OF PORRIDGES PREPARED FROM AFRICAN YAM BEAN (Sphenostylis stenocarpa) AND CORN (Zea mays) FLOUR BLENDS
}

\author{
${ }^{1 *}$ Henry-Unaeze, H.N. and ${ }^{2} \mathrm{Ngwu}$, E.K. \\ ${ }^{1}$ Department of Food Nutrition and Home Science, Faculty of Agriculture, University of Port Harcourt Choba, River \\ State, Nigeria. \\ ${ }^{2}$ Department of Nutrition and Dietetics, University of Nigeria Nsukka, Enugu State, Nigeria.
}

*Corresponding author: helen.henry-unaeze@ uniport.edu.ng

\begin{abstract}
Background: The dietary challenges facing type 2 diabetics have necessitated the development of high fiber indigenous diets for the management/control of blood glucose.

Objectives: The study determined the chemical composition, sensory and microbial attributes of porridges prepared from African yam bean (AYB) and corn flour blends.

Methods: AYB seeds roasted at $191^{\circ} \mathrm{C}$ for $40 \mathrm{~min}$ and corn oven-dried at $50^{\circ} \mathrm{C}$ for $24 \mathrm{~h}$ were finely milled, evaluated for proximate composition and dietary fiber profile and formulated into 5 flour samples in the ratios of 100, 70:30, $50: 50,30: 70,100$ to supply one-third $(1 / 3)$ of the daily dietary fiber requirement $(12.7 \mathrm{~g})$ of a reference man $(70 \mathrm{~kg})$. The 5 samples (including 3 composites) together with the control (traditional corn flour) provided 6 samples for the study. The samples were made into porridges and evaluated for chemical composition, sensory and microbial attributes using standard procedures. Data generated were analyzed using the IBM Statistical Product for Service Solution statistics version 21. Results were presented as means and standard deviations, Analysis of variance (ANOVA) was used to compare the means and significance was accepted at $\mathrm{p}<0.05$.

Results: The proximate, minerals, vitamins and phytochemical compositions of the porridges were superior to the traditional corn porridge (control). No anti-nutrients were detected in all the porridges. Flavonoids ( 0.01 to $0.04 \mathrm{mg}$ ) and saponins ( 0.01 to $0.05 \mathrm{mg}$ ) were present in the porridges but not in the control. Viable organisms (Staphylococcus aureus, Bacillus cereus, Micrococcus spp, Enterobacter aerogenes, Pencillum spp. Rhizopus spp.) that were unnatural microfloral of AYB and corn seeds were detected in the porridges. The microbial loads $\left(1.2 \times 10^{1}\right.$ to $\left.2.0 \times 10^{2} \mathrm{cfu} / \mathrm{g}\right)$ were within the acceptable International Commission on Microbiological Specification of food limits of $10^{5} \mathrm{cfu} / \mathrm{g}$. More coliforms and fungal growth were observed in porridges with higher proportions of corn. All porridges rated higher (5.08 - 6.67) on the acceptability scale than the traditional corn porridge (4.00).

Conclusion: The high-fiber AYB-corn porridges had improved nutrient content, safe microbial load and consumer acceptability than the traditional corn porridge, and will add variety to diabetic meals.
\end{abstract}

Keywords: Microbial load, chemical/sensory attributes, African yam bean, corn, porridges

\section{INTRODUCTION}

Recently, there is a global upsurge in the incidence of non-communicable diseases (NCDs) [1] of which type 2 diabetes mellitus (T2DM) is among the most common [2]. In Nigeria, a lot of people are facing the challenge of managing this life-long condition due to limited diets of proven positive effect on blood glucose level. Apprehensions about the nutritional status of the diabetics have generated lots of interest in developing therapeutic diets to add variety to available meals because evidence has shown that blood glucose can largely be controlled through dietary management [3] Indigenous foods of good nutritional qualities abound. Whole corn is among the world's most popular cereal grains, a very good source of fiber, many vitamins (folate, B-complex and ascorbic acids), minerals (magnesium, phosphorus, potassium), and antioxidants (vitamin E, ubiquinone and phytosterol) which increases its shelf-life and cholesterol lowering ability; its high contents of resistant starches is noted among various health benefits including anti-HIV activity due to its content of galanthus nivalis aggulutinin [4]. African Yam Bean (AYB) has high nutritional quality, good gelation property and high water absorption capacity [5,6] needed in diabetes management but is facing extinction due to nutrition transition. Efforts to salvage this crop and others to ensure food security and introduce variety to the diabetic diet need to be strengthened. Consequently, this study was designed to develop porridges from AYB and corn flour blends to furnish $1 / 3$ dietary fiber requirement $(12.7 \mathrm{~g})$ of a $70 \mathrm{~kg}$ man [7]. 
MATERIALS AND METHODS

Selection of subjects

Thirty diabetics from the Diabetic out-patient's clinic of the University of Nigeria Teaching Hospital Enugu willing to participate in the study were purposively selected.

Collection and preparation of the flours and composites

Coffee brown African yam bean (Sphenostylis stenocarpa) and white corn (Zea mays) seeds were purchased from Ndioro, a local market in Abia State, Nigeria. The AYB seeds were sorted to remove dirt, stones and other extraneous materials, washed with clean tap water, drained on a colander and roasted in a large saucepan over a gas burner at $191{ }^{\circ} \mathrm{C}$ (medium mark temperature calibrated the by manufacturer) for 40 minutes The roasted whole seeds were milled into flour using Saint Donkey Powder Crusher (Leshan Dongchuan) with $5 \mathrm{~mm}$ sieve and packaged in an airtight labeled high density polyethene bags. Corn seeds were also sorted to remove extraneous materials, washed with tap water, drained on a colander and oven-dried for 24 hours in a Uniscope Laboratory Oven - SM9023 (Surgifriend Medigals England) to a constant weight at $50^{\circ} \mathrm{C}$. The dried whole corn was milled into fine flour using Saint Donkey Powder Crusher. AYB and corn flours were evaluated for proximate composition, and dietary fiber profile using standard procedures $[8,9,10]$. The values obtained were used to calculate the quantity required to provide $12.7 \mathrm{~g}$ dietary fiber for each sample in the ratios of 100:0, 70:30, 50:50, 30:70, 0:100 and coded as: $S_{100}$, $S_{70} Z_{30}, S_{50} Z_{50}, S_{30} Z_{70}$, and $Z_{100}$ respectively to provide five (5) samples; Samples $S_{100}\left(100 \%\right.$ AYB) and $Z_{100}$ ( $100 \%$ corn) were milled whole different from the contemporary usage. Fermented corn flour, finely milled and sifted with muslin cloth of aperture sieve size $2 \mathrm{~mm}$ (as it is used traditionally) coded as $\mathrm{Zc}_{100}$ was used as the control. Each sample was mixed thoroughly in a Kenwood food processor at full speed for 5 min and placed in air-tight Ziploc bag, packed inside high density poly ethylene bags and stored in a deep freezer $\left(-10^{\circ} \mathrm{C}\right)$ ready for use.

\section{Preparation of the porridges}

Each of the six flour samples including the control measured in quantities $52.87 \mathrm{~g} \quad\left(\mathrm{~S}_{100} 100 \% \mathrm{AYB}\right)$, $70.85 \mathrm{~g}\left(\mathrm{~S}_{70} \mathrm{Z}_{30}-70 \%\right.$ AYB:30\% corn), 82.84g ( $\mathrm{S}_{50} \mathrm{Z}_{50}$ - 50\% AYB:50\% corn), 94.81g $\left(\mathrm{S}_{30} \mathrm{Z}_{70}-30 \%\right.$ AYB:70\% corn), $112.79 \mathrm{~g}\left(\mathrm{Z}_{100}-100 \%\right.$ corn $)$, and $104.18\left(\mathrm{Zc}_{100}\right.$ traditional corn flour $)$ that will contribute $1 / 3$ of the daily dietary fiber intake as constituted from their chemical composition were mixed with $200 \mathrm{ml}$ cold water to get a watery slurry, additional $300 \mathrm{ml}$ of boiling hot water was added to the mixture while stirring. The mixture was placed on gas burner at $191{ }^{\circ} \mathrm{C}$ and another $100 \mathrm{ml}$ of the boiling water added while still stirring for 60s. Sweeteners (Canderel 4 tablets) were added to sweeten each of the porridge samples.

\section{Chemical analysis}

The proximate compositions were determined using standard procedures [8], total carbohydrate was obtained by difference and energy values were calculated using the Atwater factors. Minerals (calcium, iron, magnesium, potassium and sodium), vitamins (beta carotene, thiamin, riboflavin, niacin and vitamin $\mathrm{C}$ ), and phytochemicals (phenol, flavonoids and saponins) were determined by AOAC [8]. Antinutrients (phytic acid, total tannins, and trypsin inhibitor) were determined using standard methods $[11,12]$.

\section{Microbial load assessment of the porridges}

International Commission on Microbiological Specifications for Foods [13] standard method was used to determine the microbial loads of the porridges. Ten grams of each porridge were soaked in $90 \mathrm{ml}$ of sterile distilled water to obtain a one in ten serial dilutions of the aqueous samples to the third stage $\left(10^{3}\right)$. Pour plate method [14] was used to mix $0.1 \mathrm{ml}$ of the third stage diluents and $25 \mathrm{ml}$ of cooled molten sterile nutrient agar. Mackonkey and Oxytetracycline Glucose Yeast Extract (OGYE) were also mixed with $0.1 \mathrm{ml}$ of the third stage diluents respectively and the media incubated at $37{ }^{\circ} \mathrm{C}$ overnight (3-5days for yeast and mold). Plate Count Agar (Oxoid CM463) was used for the enumeration of aerobic colony counts (ACC), Mackonkey agar (Oxoid CM7) for the enterobacteriaceae count (EC) and OGYE for the yeast and mold. The colony forming units were determined using an electronic colony counter (Gallenkamp colony counter, UK). The colony forming unit per gram $\left(\mathrm{cfu} \mathrm{g}^{-1}\right)$ was calculated by multiplying the count by the dilution factor. Pure cultures were used to identify pathogenic bacteria, coliforms, yeast and mold.

Evaluation of sensory attributes of the porridges Sensory evaluation of the porridges in terms of consistency, flavor, taste, color and general acceptability was performed as described [15] with 36 untrained panelists (out-patient diabetics) who consented to the study. The porridges were rated on a 7 -point hedonic scale where 7 represented the highest score - liked extremely and 1 the lowest score extremely disliked. The mean scores for sensory attributes were recorded.

\section{Statistical analysis}

Data generated were analyzed using the IBM SPSS Statistics version 21. Results were presented as means and standard deviations, Analysis of variance (ANOVA) was used to compare the means, Duncan's multiple range test was used to separate means and levels of significance was accepted at $\mathrm{p}<0.05$. 


\section{RESULTS}

The energy content of the porridges (Table 1) ranged from 46.34 - 239.07kcals. Sample $\mathrm{S}_{100}(100 \%$ AYB) had higher energy value $(54.02 \mathrm{kcal})$ than sample $\mathrm{Z}_{100}$ (100\% Corn). The moisture content of the porridges increased from $40.25 \%$ in $\mathrm{S}_{100}(100 \% \mathrm{AYB})$ to $88.51 \%$ in $\mathrm{Z}_{100}(100 \%$ Corn). The protein ranged from $2.67 \%$ in $\mathrm{S}_{100}(100 \% \mathrm{AYB})$ to $6.84 \%$ in $\mathrm{Z}_{100}(100 \%$ Corn), higher than $0.77 \%$ in the control $\mathrm{Zc}_{100}(100 \%$ fermented corn porridge). The carbohydrate value of the porridges ranged from $56.67 \%$ in $\mathrm{S}_{100}(100 \%$ AYB) to $3.53 \%$ in $\mathrm{Z}_{100}(100 \%$ Corn).

Table 1: Energy and proximate compositions of the porridges *

\begin{tabular}{lllllll}
\hline $\begin{array}{l}\text { Sample } \\
\text { Quantity (g) }\end{array}$ & Energy (Kcal) & Moisture $(\%)$ & Protein $(\%)$ & $\begin{array}{l}\text { Fat } \\
(\%)\end{array}$ & $\begin{array}{c}\text { Ash } \\
(\%)\end{array}$ & Crude Crude Fiber $(\%)$ \\
\hline$S_{100}(52.87)$ & $239.07^{\mathrm{a}} \pm 0.13$ & $40.25^{\mathrm{f}} \pm 0.00$ & $2.67^{\mathrm{e}} \pm 0.10$ & $0.19^{\mathrm{e}} \pm 0.04$ & $0.22^{\mathrm{f}} \pm 0.01$ & $0.14^{\mathrm{c}} \pm 0.01$ \\
$\mathrm{~S}_{70} \mathrm{Z}_{30}(70.85)$ & $180.49^{\mathrm{b}} \pm 0.01$ & $54.91^{\mathrm{e}} \pm 0.01$ & $3.92^{\mathrm{d}} \pm 0.08$ & $0.29^{\mathrm{d}} \pm 0.07$ & $0.33^{\mathrm{e}} \pm 0.01$ & $0.16^{\mathrm{b}} \pm 0.08$ \\
$\mathrm{~S}_{50} \mathrm{Z}_{50}(82.84)$ & $142.60^{\mathrm{c}} \pm 0.09$ & $64.40^{\mathrm{d}} \pm 0.03$ & $4.76^{\mathrm{c}} \pm 0.04$ & $0.36^{\mathrm{c}} \pm 0.10$ & $0.40^{\mathrm{c}} \pm 0.01$ & $0.17^{\mathrm{b}} \pm 0.00$ \\
$\mathrm{~S}_{30} \mathrm{Z}_{70}(94.81)$ & $103.32^{\mathrm{d}} \pm 0.08$ & $74.25^{\mathrm{c}} \pm 0.05$ & $5.58^{\mathrm{b}} \pm 0.02$ & $0.44^{\mathrm{b}} \pm 0.02$ & $0.47^{\mathrm{b}} \pm 0.01$ & $0.18^{\mathrm{b}} \pm 0.06$ \\
$\mathrm{Z}_{100}(112.79)$ & $46.34^{\mathrm{f}} \pm 0.06$ & $88.51^{\mathrm{a}} \pm 0.01$ & $6.84^{\mathrm{a}} \pm 0.07$ & $0.54^{\mathrm{a}} \pm 0.08$ & $0.58^{\mathrm{a}} \pm 0.03$ & $0.20^{\mathrm{a}} \pm 0.01$ \\
$\mathrm{Zc}_{100}(104.18)$ & $54.03^{\mathrm{e}} \pm 0.03$ & $86.32^{\mathrm{b}} \pm 0.06$ & $0.77^{\mathrm{f}} \pm 0.00$ & $0.15^{\mathrm{f}} \pm 0.00$ & $0.36^{\mathrm{d}} \pm 0.05$ & $0.08^{\mathrm{d}} \pm 0.03$ \\
\hline
\end{tabular}

Values are mean, \pm SD of triplicate determinations; Means with similar superscript in the same column are not significantly $(\mathrm{P}<0.05)$ different; $\mathrm{S}_{100}=100 \%$ Sphenostylis stenocarpa; $\mathrm{S}_{70} \mathrm{Z}_{30}=70 \%$ Sphenostylis stenocarpa $: 30 \%$ Zea may; $\mathrm{S}_{50} \mathrm{Z}_{50}=50 \%$ Sphenostylis stenocarpa $: 50 \%$ Zea mays $5_{50} ; \mathrm{S}_{30} \mathrm{Z}_{70}=30 \%$ Sphenostylis stenocarpa $: 70 \%$ Zea mays $70 ; Z_{100}=100 \%$ Zea mays; the control $\mathrm{Zc}_{100}=100 \%$ fermented refined Zea mays.

The mineral and vitamin compositions of the porridges prepared (Table 2) from the blends shows that the calcium content of the porridges ranged from 43.99 $\mathrm{mg}$ in $\mathrm{S}_{100}(100 \% \mathrm{AYB})$ to $83.59 \mathrm{mg}$ in $\mathrm{Z}_{100}(100 \%$ Corn). Sample $S_{100}(100 \%$ AYB) had the lowest iron and magnesium values of $0.32 \mathrm{mg}$ and $4.34 \mathrm{mg}$, respectively. $Z_{100}(100 \%$ Corn) had more $(64.40 \mathrm{mg})$ sodium than $\mathrm{S}_{100}(100 \%$ AYB $) 24.01 \mathrm{mg}$. The potassium range was from $11.17 \mathrm{mg}$ in $\mathrm{S}_{100}(100 \%$ AYB) to $36.92 \mathrm{mg}$ in $\mathrm{Z}_{100}(100 \%$ Corn). The beta carotene value of the porridges ranged from $4.0 \mu \mathrm{g}$ in $\mathrm{S}_{100}(100 \% \mathrm{AYB})$ to $6.07 \mu \mathrm{g}$ in $\mathrm{Z}_{100}(100 \%$ Corn).

Table 2: Mineral and vitamin composition of the porridges

\begin{tabular}{|c|c|c|c|c|c|c|}
\hline \multirow{2}{*}{$\begin{array}{l}\text { Mineral and } \\
\text { vitamin }\end{array}$} & \multirow[b]{2}{*}{$S_{100}(52.87)$} & \multirow[b]{2}{*}{$\begin{array}{l}S_{70} Z_{30} \\
(\mathbf{7 0 . 8 5})\end{array}$} & \multicolumn{2}{|c|}{ Sample (quantity in grams) } & \multirow[b]{2}{*}{$Z_{100}(112.79)$} & \multirow[b]{2}{*}{$\begin{array}{l}Z_{100} \\
(104.18)\end{array}$} \\
\hline & & & $\begin{array}{l}S_{50} Z_{50} \\
(82.84)\end{array}$ & $\begin{array}{l}S_{30} Z_{70} \\
(94.81)\end{array}$ & & \\
\hline \multicolumn{7}{|l|}{ Mineral } \\
\hline $\mathrm{Ca}(\mathrm{mg})$ & $43.99^{f} \pm 0.01$ & $55.88^{\mathrm{d}} \pm 0.00$ & $63.81^{\mathrm{c}} \pm 0.03$ & $71.73^{b} \pm 0.06$ & $83.59^{\mathrm{a}} \pm 0.01$ & $53.73^{\mathrm{e}} \pm 0.02$ \\
\hline $\mathrm{Fe}(\mathrm{mg})$ & $0.32^{\mathrm{f}} \pm 0.03$ & $0.59^{\mathrm{e}} \pm 0.06$ & $0.75^{\mathrm{d}} \pm 0.08$ & $0.93^{c} \pm 0.02$ & $1.18^{\mathrm{b}} \pm 0.00$ & $1.25^{\mathrm{a}} \pm 0.01$ \\
\hline $\mathrm{Mg}(\mathrm{mg})$ & $4.34^{\mathrm{f}} \pm 1.05$ & $6.52^{\mathrm{e}} \pm 1.12$ & $7.97^{\mathrm{d}} \pm 0.04$ & $9.42^{\mathrm{c}} \pm 0.14$ & $11.60^{\mathrm{b}} \pm 0.09$ & $12.51^{\mathrm{a}} \pm 0.12$ \\
\hline $\mathrm{Na}(\mathrm{mg})$ & $24.01^{\mathrm{e}} \pm 0.00$ & $36.13^{\mathrm{d}} \pm 0.09$ & $44.21^{\mathrm{c}} \pm 0.06$ & $52.28^{\mathrm{b}} \pm 0.15$ & $64.40^{\mathrm{a}} \pm 0.19$ & $19.61^{\mathrm{f}} \pm 0.01$ \\
\hline $\mathrm{K}(\mathrm{mg})$ & $11.17^{f} \pm 0.03$ & $18.89^{\mathrm{d}} \pm 0.06$ & $24.04^{\mathrm{c}} \pm 0.09$ & $29.19^{\mathrm{b}} \pm 0.00$ & $36.92^{\mathrm{a}} \pm 0.11$ & $14.60^{\mathrm{e}} \pm 0.01$ \\
\hline \multicolumn{7}{|l|}{ Vitamin } \\
\hline$\beta$-carotene & & & & & & \\
\hline$(\mu \mathrm{g})$ & $4.01^{\mathrm{e}} \pm 0.01$ & $4.62^{\mathrm{d}} \pm 0.05$ & $5.03^{\mathrm{c}} \pm 0.00$ & $5.45^{b} \pm 0.01$ & $6.07^{\mathrm{a}} \pm 0.10$ & $1.06^{\mathrm{f}} \pm 0.00$ \\
\hline $\mathrm{B}_{1}(\mathrm{mg})$ & $0.16^{\mathrm{e}} \pm 0.12$ & $0.18^{\mathrm{d}} \pm 0.17$ & $0.20^{\mathrm{c}} \pm 0.01$ & $0.22^{\mathrm{b}} \pm 0.01$ & $0.24^{\mathrm{a}} \pm 0.10$ & $0.06^{\mathrm{f}} \pm 0.00$ \\
\hline $\mathrm{B}_{2}(\mathrm{mg})$ & $0.00^{\mathrm{a}} \pm 0.00$ & $0.00^{\mathrm{a}} \pm 0.00$ & $0.00^{\mathrm{a}} \pm 0.00$ & $0.00^{\mathrm{a}} \pm 0.00$ & $0.00^{\mathrm{a}} \pm 0.00$ & $0.00^{\mathrm{a}} \pm 0.00$ \\
\hline $\mathrm{B}_{3}(\mathrm{mg})$ & $0.50^{\mathrm{a}} \pm 0.01$ & $0.44^{\mathrm{b}} \pm 0.06$ & $0.41^{\mathrm{c}} \pm 0.01$ & $0.37^{\mathrm{d}} \pm 0.02$ & $0.32^{\mathrm{e}} \pm 0.05$ & $0.01^{\mathrm{f}} \pm 0.06$ \\
\hline $\mathrm{C}(\mathrm{mg})$ & $3.60^{\mathrm{e}} \pm 0.01$ & $3.66^{\mathrm{d}} \pm 0.10$ & $3.72^{\mathrm{c}} \pm 0.13$ & $3.75^{\mathrm{b}} \pm 0.15$ & $3.82^{\mathrm{a}} \pm 0.06$ & $1.10^{\mathrm{f}} \pm 0.01$ \\
\hline
\end{tabular}

Values are mean, \pm SD of triplicate determinations; Means with similar superscript in the same column are not significantly $(\mathrm{P}<0.05)$ different; $\mathrm{S}_{100}=100 \%$ Sphenostylis stenocarpa $; \mathrm{S}_{70} \mathrm{Z}_{30}=70 \%$ Sphenostylis stenocarpa $: / 30 \%$ Zea may; $\mathrm{S}_{50} \mathrm{Z}_{50}=50 \%$ Sphenostylis stenocarpa $: 150 \%$ Zea mays ${ }_{50} ; \mathrm{S}_{30} \mathrm{Z}_{70}=30 \%$ Sphenostylis stenocarpa $: 70 \%$ Zea mays; $\mathrm{Z}_{100}=100 \%$ Zea mays; the control $\mathrm{Zc}_{100}=100 \%$ fermented refined Zea mays.

Table 3 presents the phytochemical and anti-nutrient compositions of the porridges. The phenol, phytate, tannin and trypsin inhibitor in the test porridges were reduced and not detected. The values of flavonoids and
These values were higher than $1.06 \mu \mathrm{g}$ in the control $\mathrm{Zc}_{100}$ (100\% fermented corn porridge). The range of thiamin in the test porridges was from $0.16 \mathrm{mg}$ in $S_{100}$ (100\% AYB) to $0.24 \mathrm{mg}$ in $\mathrm{Z}_{100}$ (100\% Corn). Fermented corn porridge $\left(\mathrm{Zc}_{100}\right)$ had the lowest thiamin content. Riboflavin was not detected in the all the test porridges while niacin ranged from $0.32 \mathrm{mg}$ in $\mathrm{Z}_{100}\left(100 \%\right.$ Corn) to $0.5 \mathrm{mg}$ in $\mathrm{S}_{100}(100 \% \mathrm{AYB})$. Fermented corn porridge $\left(\mathrm{Zc}_{100}\right)$ had much lower niacin content. The vitamin $C$ value was lowest (1.10 $\mathrm{mg}$ ) in $\mathrm{Zc}_{100}$ (100\% fermented corn) and highest in $\mathrm{Z}_{100}$ (100\% Corn). 
Journal of Dietitians Association of Nigeria (JDAN) Volume 12. December, 2021 Print ISSN: 2141-8209; eISSN: 2635-3326

Available online at: www.jdan.org.ng; https://www.ajol.info/index.php/jdan/index

DOI: https://dx.doi.org/10.4314/jdan.v12i1.3

Table: 3 Phytochemical and anti-nutrient compositions of the porridge samples.

\begin{tabular}{lllllll}
\hline Sample & $\begin{array}{l}\text { Phenol } \\
(\mathrm{mg})\end{array}$ & $\begin{array}{l}\text { Flavonoid } \\
(\mathrm{mg})\end{array}$ & $\begin{array}{l}\text { Saponin } \\
(\mathrm{mg})\end{array}$ & $\begin{array}{l}\text { Phytate } \\
(\mathrm{mg})\end{array}$ & $\begin{array}{l}\text { Tannin } \\
(\mathrm{mg})\end{array}$ & Trypsin inhibitor (TIU/mg) \\
\hline $\mathrm{S}_{100}(52.87)$ & $\mathrm{ND}$ & $0.04^{\mathrm{a}} \pm 0.02$ & $0.05^{\mathrm{a}} \pm 0.01$ & ND & ND & ND \\
$\mathrm{S}_{70} Z_{30}(70.85)$ & ND & $0.03^{\mathrm{ab}} \pm 0.01$ & $0.04^{\mathrm{a}} \pm 0.02$ & ND & ND & ND \\
$\mathrm{S}_{50} Z_{50}(82.84)$ & ND & $0.02^{\mathrm{ab}} \pm 0.01$ & $0.02^{\mathrm{b}} \pm 0.01$ & ND & ND & ND \\
$\mathrm{S}_{30} Z_{70}(94.81)$ & ND & $0.01^{\mathrm{ab}} \pm 0.01$ & $0.01^{\mathrm{b}} \pm 0.00$ & ND & ND & ND \\
$Z_{100}(112.79)$ & ND & ND & ND & ND & ND & ND \\
$Z_{100}(104.18)$ & ND & ND & ND & ND & ND & ND \\
\hline
\end{tabular}

Values are mean \pm SD of triplicate determinations; Means with similar superscript in the same column are not significantly $(\mathrm{P}<0.05)$ different; $\mathrm{S}_{100}=100 \%$ Sphenostylis stenocarpa; $\mathrm{S}_{70} \mathrm{Z}_{30}=70 \%$ Sphenostylis stenocarpa: $30 \%$ Zea may; $\mathrm{S}_{50} \mathrm{Z}_{50}=50 \%$ Sphenostylis stenocarpa $: 50 \%$ Zea mays; $\mathrm{S}_{30} \mathrm{Z}_{70}=30 \%$ Sphenostylis stenocarpa $: 70 \%$ IZea mays; $\mathrm{Z}_{100}=100 \%$ Zea mays; the control $\mathrm{Zc}_{100}=100 \%$ fermented refined Zea mays.

Table 4 shows the mean sensory properties scores of the porridges prepared from African Yam bean (Sphenostylis stenocarpa) and Corn (Zea mays) seed flour. Sample $\mathrm{S}_{50} \mathrm{Z}_{50}$ (50\% AYB: 50\% Corn) had the highest mean score (6.19) for color while $\mathrm{S}_{30} \mathrm{Z}_{70}(30 \%$ AYB: 70\% Corn) had the least score (5.78). There was a general decrease in the mean scores of flavor of porridges made from $S_{100}\left(100 \%\right.$ AYB), $S_{70} Z_{30}(70 \%$ AYB: $30 \%$ Corn), $\mathrm{S}_{50} \mathrm{Z}_{50}(50 \%$ AYB: $50 \%$ Corn), $S_{30} Z_{70}\left(30 \%\right.$ AYB: $70 \%$ Corn), $Z_{100}(100 \%$ Corn) and $\mathrm{Zc}_{100}$ (100\% fermented corn) respectively. $\mathrm{Zc}_{100}$ (4.05) had the least flavor value and $S_{100}(100 \%$ AYB $)$ had the highest flavor (5.83). $S_{100}\left(100 \%\right.$ AYB) and $S_{70} Z_{30}$ (70\% AYB: $30 \%$ Corn) were not significantly (P < $0.05)$ different in terms of flavor, but were different from $\mathrm{S}_{50} \mathrm{Z}_{50}\left(50 \%\right.$ AYB: $50 \%$ Corn) and $\mathrm{S}_{30} \mathrm{Z}_{70}(30 \%$ AYB: $70 \%$ Corn) which on their own were not significantly $(\mathrm{P}<0.05)$ different from each other. Both the latter and the former pairs were significantly $(\mathrm{P}<$ $0.05)$ different from $Z_{100}(100 \%$ Corn $)$ in terms of flavor. For consistency attribute, $100 \%$ fermented corn $\left(\mathrm{Zc}_{100}\right)$ was more (6.94) acceptable while $\mathrm{S}_{30} \mathrm{Z}_{70}$ (30\% AYB: 70\% Corn) had the least score (5.22). Consistency showed no significant $(\mathrm{P}<0.05)$ differences between porridges made with $\mathrm{S}_{50} \mathrm{Z}_{50}(50 \%$ AYB: $50 \%$ Corn), $\mathrm{S}_{30} \mathrm{Z}_{70}(30 \%$ AYB: $70 \%$ Corn) and $\mathrm{Z}_{100}(100 \%$ Corn), but these were significantly $(\mathrm{P}<0.05)$ different from $\mathrm{S}_{100}(100 \%$ AYB $)$ and $\mathrm{S}_{70} \mathrm{Z}_{30}$ (70\% AYB: $30 \%$ Corn) respectively. $\mathrm{S}_{100}(100 \%$ AYB) had the highest mean score for taste (6.72) while $Z_{100}(100 \%$ Corn) had the least score (4.81). All samples were significantly $(\mathrm{P}<0.05)$ different in terms of taste. $\mathrm{S}_{100}(100 \% \mathrm{AYB})$ had the highest score for general acceptability (6.67) and $\mathrm{Zc}_{100}(100 \%$ fermented corn) had the least score (4.00). $S_{50} Z_{50}$ and $\mathrm{S}_{30} \mathrm{Z}_{70}(30 \%$ AYB: $70 \%$ Corn) were not significantly different at $\mathrm{P}<0.05$ but both were significantly different from $S_{100}\left(100 \%\right.$ AYB), $S_{70} Z_{30}$ (70\% AYB: $30 \%$ Corn) and $\mathrm{Z}_{100}(100 \%$ Corn) respectively for general acceptability.

Table 4: Mean sensory properties scores of the porridges

\begin{tabular}{cccccc}
\hline Sample & Color & Flavor & Consistency & Taste & $\begin{array}{c}\text { General } \\
\text { acceptability }\end{array}$ \\
\hline $\mathrm{S}_{100}$ & $6.11^{\mathrm{a}} \pm 1.14$ & $5.83^{\mathrm{a}} \pm 1.89$ & $6.33^{\mathrm{b}} \pm 1.12$ & $6.72^{\mathrm{a}} \pm 0.45$ & $6.67^{\mathrm{a}} \pm 0.63$ \\
$\mathrm{~S}_{70} \mathrm{Z}_{30}$ & $6.12^{\mathrm{a}} \pm 0.81$ & $5.69^{\mathrm{a}} \pm 1.52$ & $5.92^{\mathrm{bc}} \pm 1.05$ & $6.19^{\mathrm{b}} \pm 0.67$ & $6.32^{\mathrm{ab}} \pm 0.88$ \\
$\mathrm{~S}_{50} \mathrm{Z}_{50}$ & $6.19^{\mathrm{a}} \pm 0.82$ & $5.39^{\mathrm{ab}} \pm 1.44$ & $5.44^{\mathrm{c}} \pm 1.16$ & $5.58^{\mathrm{c}} \pm 1.46$ & $6.17^{\mathrm{b}} \pm 0.88$ \\
$\mathrm{~S}_{30} \mathrm{Z}_{70}$ & $5.78^{\mathrm{a}} \pm 0.90$ & $5.09^{\mathrm{ab}} \pm 1.69$ & $5.22^{\mathrm{c}} \pm 1.71$ & $5.31^{\mathrm{cd}} \pm 1.31$ & $5.89^{\mathrm{b}} \pm 0.85$ \\
$\mathrm{Z}_{100}$ & $6.03^{\mathrm{a}} \pm 0.69$ & $4.83^{\mathrm{b}} \pm 1.80$ & $5.28^{\mathrm{c}} \pm 1.78$ & $4.81^{\mathrm{e}} \pm 1.33$ & $5.08^{\mathrm{c}} \pm 1.50$ \\
$\mathrm{Zc}_{100}$ & $6.00^{\mathrm{b}} \pm 0.19$ & $4.05^{\mathrm{c}} \pm 0.62$ & $6.94^{\mathrm{a}} \pm 1.27$ & $5.00^{\mathrm{d}} \pm 1.36$ & $4.00^{\mathrm{d}} \pm 0.34$ \\
\hline
\end{tabular}

Values are mean \pm SD of triplicate determinations; Means with similar superscript in the same column are not significantly $(\mathrm{P}<0.05)$ different; $\mathrm{S}_{100}=100 \%$ Sphenostylis stenocarpa; $\mathrm{S}_{70} \mathrm{Z}_{30}=70 \%$ Sphenostylis stenocarpa 7 : $30 \%$ Zea may ${ }_{30} ; \mathrm{S}_{50} \mathrm{Z}_{50}=50 \%$ Sphenostylis stenocarpa: $50 \%$ Zea mays; $\mathrm{S}_{30} \mathrm{Z}_{70}=30 \%$ Sphenostylis stenocarpa $: 70 \%$ IZea mays; $\mathrm{Z}_{100}=100 \%$ Zea mays; the control $\mathrm{Zc}_{100}=100 \%$ fermented refined Zea mays.

The microbial population of the experimental porridges (Table 5) shows that the total viable count (TVC) for the porridges ranged from $1.2 \times 10^{1} \pm 1.02$ in the $\mathrm{S}_{100}(100 \% \mathrm{AYB})$ to $1.5 \times 10^{2} \pm 0.06$ in $\mathrm{Zc}_{100}$ (100\% fermented corn) and coliform from $3.0 \times 10^{1} \pm$ 0.20 in the $\mathrm{S}_{30} \mathrm{Z}_{70}$ (30\% AYB: $70 \%$ Corn) to $2.0 \times 10^{2}$ \pm 0.15 in the $\mathrm{Zc}_{100}$ (100\% fermented corn). No visible growth of coliform was observed in the samples $S_{100}$ (100\% AYB), $S_{70} Z_{30}\left(70 \%\right.$ AYB: $30 \%$ Corn) and $Z_{100}$ (100\% Corn) while the $S_{50} Z_{50}$ (50\% AYB: $50 \%$ Corn), the $\mathrm{S}_{30} \mathrm{Z}_{70}\left(30 \%\right.$ AYB: $70 \%$ Corn) and $\mathrm{Zc}_{100}(100 \%$ fermented corn) had $7.0 \times 10^{1} \pm 0.08,3.0 \times 10^{1} \pm 0.20$ 
DOI: https://dx.doi.org/10.4314/jdan.v12i1.3

and $2.0 \times 10^{2} \pm 0.15$, respectively. Mold and yeast ranged from $1.0 \times 10^{1} \pm 0.19$ in the $\mathrm{Z}_{100}(100 \%$ Corn) to $2.0 \times 10^{1} \pm 1.13$ in $\mathrm{Zc}_{100}$ (100\% fermented corn). No visible growth of mold or yeast was observed in the Table 5: Microbial population of the porridges prepared

\begin{tabular}{llll}
\hline Samples & TVC & Coliform counts & Mold yeast counts \\
\hline $\mathrm{S}_{100}$ & $1.2 \times 10^{1} \pm 1.02^{\mathrm{c}}$ & $\mathrm{NG}$ & NG \\
$\mathrm{S}_{70} \mathrm{Z}_{30}$ & $9.7 \times 10^{1} \pm 0.02^{\mathrm{a}}$ & NG & NG \\
$\mathrm{S}_{50} \mathrm{Z}_{50}$ & $9.2 \times 10^{1} \pm 0.01^{\mathrm{a}}$ & $7.0 \times 10^{1} \pm 0.08^{\mathrm{a}}$ & NG \\
$\mathrm{S}_{30} \mathrm{Z}_{70}$ & $8.4 \times 10^{1} \pm 1.10^{\mathrm{b}}$ & $3.0 \times 10^{1} \pm 0.20^{\mathrm{b}}$ & NG \\
$\mathrm{Z}_{100}$ & $1.6 \times 10^{1} \pm 0.04^{\mathrm{c}}$ & $\mathrm{NG}$ & $1.0 \times 10^{1} \pm 0.19^{\mathrm{b}}$ \\
$\mathrm{Zc}_{100}$ & $1.5 \times 10^{2} \pm 0.06^{\mathrm{c}}$ & $2.0 \times 10^{2} \pm 0.15^{\mathrm{c}}$ & $2.0 \times 10^{1} \pm 1.13^{\mathrm{a}}$ \\
\hline
\end{tabular}

Values are mean \pm SD of triplicate determinations; Means with similar superscript in the same column are not significantly $(\mathrm{P}<0.05)$ different; $\mathrm{S}_{100}=100 \%$ Sphenostylis stenocarpa; $\mathrm{S}_{70} \mathrm{Z}_{30}=70 \%$ Sphenostylis stenocarpa 7 : $30 \%$ Zea may ${ }_{30} ; \mathrm{S}_{50} \mathrm{Z}_{50}=50 \%$ Sphenostylis stenocarpa: $50 \%$ Zea mays; $\mathrm{S}_{30} \mathrm{Z}_{70}=30 \%$ Sphenostylis stenocarpa $: 70 \%$ IZea mays; $\mathrm{Z}_{100}=100 \%$ Zea mays; the control $\mathrm{Zc}_{100}=100 \%$ fermented refined Zea mays, $\mathrm{NG}=$ no visible growth

The bacterial and fungal profile isolated from the test porridges (Table 6) shows that Staphylococcus aureus and bacillus cereus were present in all the porridges. The Micrococcus spp was found only in the sample $\mathrm{S}_{100}(100 \% \mathrm{AYB})$, Enterobacter aerogenes in samples samples $\mathrm{S}_{100}\left(100 \%\right.$ AYB), $\mathrm{S}_{70} \mathrm{Z}_{30}(70 \%$ AYB: $30 \%$ Corn), $\mathrm{S}_{50} \mathrm{Z}_{50}\left(50 \%\right.$ AYB: $50 \%$ Corn) and $\mathrm{S}_{30} \mathrm{Z}_{70}(30 \%$ AYB: $70 \%$ Corn)
$\mathrm{S}_{70} \mathrm{Z}_{30}\left(70 \%\right.$ AYB: $30 \%$ Corn), $\mathrm{S}_{50} \mathrm{Z}_{50}(50 \%$ AYB: $50 \%$ Corn), $\mathrm{Z}_{100}\left(100 \%\right.$ Corn) and $\mathrm{Zc}_{100}$ (100\% fermented corn porridge) while Pencillum spp. and Rhizopus spp. were isolated in $\mathrm{Z}_{100}\left(100 \%\right.$ Corn) and $\mathrm{Zc}_{100}(100 \%$ fermented corn porridge) respectively

Table 6: Bacteria and fungi isolated from the porridges

\begin{tabular}{|c|c|c|c|c|c|c|}
\hline Isolates & $\mathbf{S}_{100}$ & $\mathbf{S}_{70} \mathbf{Z}_{30}$ & $\mathbf{S}_{50} Z_{50}$ & $\mathbf{S}_{30} Z_{70}$ & $\mathbf{Z}_{100}$ & $\mathbf{Z c}_{100}$ \\
\hline Staphylococcus aureus & + & + & + & + & + & + \\
\hline Bacillus cereus & - & - & - & - & - & + \\
\hline Micrococcus spp. & + & - & - & - & - & - \\
\hline Escherichia coli & - & - & - & - & - & - \\
\hline Enterobacter aerogenes & - & + & + & - & + & + \\
\hline Aspergillus flavus & - & - & - & - & - & - \\
\hline Pencillum spp. & - & - & - & - & + & + \\
\hline Rhizopus spp. & - & - & - & - & + & + \\
\hline
\end{tabular}

Values are mean \pm SD of triplicate determinations; Means with similar superscript in the same column are not significantly $(\mathrm{P}<0.05)$ different; $\mathrm{S}_{100}=100 \%$ Sphenostylis stenocarpa; $\mathrm{S}_{70} \mathrm{Z}_{30}=$ Sphenostylis stenocarpa ${ }_{70} /$ Zea may $_{30} ; \mathrm{S}_{50} \mathrm{Z}_{50}=$ Sphenostylis stenocarpa ${ }_{50} /$ Zea mays ${ }_{50} ; \mathrm{S}_{30} \mathrm{Z}_{70}=$ Sphenostylis stenocarpa $30 /$ Zea $_{\text {mays }} ; \mathrm{Z}_{100}=100 \%$ Zea mays; the control $\mathrm{Zc}_{100}=100 \%$ fermented refined Zea mays $+=$ presence; $-=$ absence .

\section{DISCUSSION}

The moisture contents of the porridges increased as the quantities of the flour samples used in making the porridges increased (Table 1). This was expected as water absorption capacity increases with increase in the incorporation of more flour [16]. Samples $\mathrm{Z}_{100}$ (100\% Corn) and $\mathrm{Zc}_{100}$ (100\% fermented corn porridge, the control) with weight values of $112.79 \mathrm{~g}$ and $104.18 \mathrm{~g}$ respectively had higher moisture contents in line with their weight when compared with the other samples weighing between 52.87 to $94.81 \mathrm{~g}$. These high moisture values of $\mathrm{Z}_{100}\left(100 \%\right.$ Corn) and $\mathrm{Zc}_{100}$ (100\% fermented corn) porridges also reduced their other proximate values. The test porridges had higher protein contents $(2.67-6.84 \%)$ than the control $\mathrm{Zc}_{100}$ (traditional corn porridge) $(0.77 \%)$. This is in consonance with Aguilera et al. [17] report of reduced 
possible when the weight of these samples (52.87 to $94.81 \mathrm{~g}$ compared to $112.79 \mathrm{~g}$ shown in table 1) that supplied the improved dietary fiber was considered. The protein content of porridges though less than the daily requirement for adults will add to the protein content of the diets.

The increase in ash across the porridges implied increased mineral components. The ash contents of the porridges in this work were lower than that (1.5-2.5\%) reported for porridges made from malted barley, maize and roasted pea flour [19] probably because of malting shown to increase nutrient contents of foods [20]. The carbohydrate content of the porridges was appreciably lower than $69-71 \%$ reported in soy and cowpea enriched maize gruel [21] and 91-95\% in pigeon pea and sorghum enriched gruel [6]. The lower carbohydrate and energy value of samples $Z_{100}(100 \%$ corn porridge) and the control $\mathrm{Zc}_{100}(100 \%$ fermented refined corn porridge) was due to their higher moisture value which reduced their proximate density when compared with the other porridges. The lower carbohydrate content of the test porridges would be highly appreciated in diabetic diets as the amount of total carbohydrate determines the blood glucose response.

The quantity of the porridges in grams influenced their minerals composition (Table 2). Porridges with smaller quantities had lower mineral contents as the differences in the quantities of the porridges were determined by the amount of test flour required to provide the $1 / 3$ of adult daily dietary fiber recommendation. Oghbaei and Prakash [22] reported reduction in mineral contents of cereals and legumes during milling and emphasized their improved availability due to reduction in anti-nutrient content. The porridges had higher beta-carotene values (4.01 to $6.07 \mu \mathrm{g})$ than the control $(1.06 \mu \mathrm{g})$. The lower value of vitamin $\mathrm{C}$ in the control was expected as vitamin $\mathrm{C}$ is easily lost during traditional methods of cooking [23]. This is in consonance with the report of nutrient losses during milling [24]. Processing methods can influence the phytochemical and anti-nutrient composition of food samples [25]. The phenol, phytate, tannin and trypsin inhibitor in the test porridges were reduced entirely and will thus not inhibit the absorption of other essential nutrients from the porridges. Oghbaei and Prakash [22] reported improved bioavailability and absorption of essential nutrients with reduction in phytic acid and polyphenols of diets. Similarly, Onyeike and Omubo [26] reported decreased antinutrients of AYB by heat treatment. Soaking and milling completely reduced the phytochemicals and anti-nutrients value of the control $\left(\mathrm{Zc}_{100}\right)$ sample. $\mathrm{Xu}$ and Chang [27] reported reduction in soluble and insoluble dietary fiber, phytic acid, polyphenol and tannin through soaking, dehulling and cooking. The flavonoids and saponin in the porridges could be beneficial because of their antioxidant activity [28].

The mean sensory ratings of the porridges prepared from flour blends (Table 4) showed that $\mathrm{S}_{50} \mathrm{Z}_{50}(50 \%$ AYB: $50 \%$ Corn porridge) was more acceptable for color and there was a general decrease in the mean scores of flavor of samples $\mathrm{S}_{100}\left(100 \%\right.$ AYB), $\mathrm{S}_{70} \mathrm{Z}_{30}$ (70\% AYB: $30 \%$ Corn), $\mathrm{S}_{50} \mathrm{Z}_{50}(50 \%$ AYB: $50 \%$ Corn), $\mathrm{S}_{30} \mathrm{Z}_{70}\left(30 \%\right.$ AYB: $70 \%$ Corn), $\mathrm{Z}_{100}(100 \%$ Corn) to $Z_{\mathrm{c} 100}(100 \%$ fermented corn) porridges. This was understandable as roasting imparted a more acceptable flavor than fermentation. $\mathrm{Zc}_{100}$ (traditional fermented corn porridge) was more acceptable for consistency because of its very refined form. The similarity in samples $\mathrm{S}_{50} \mathrm{Z}_{50}(50 \%$ AYB: $50 \%$ Corn), $\mathrm{S}_{30} \mathrm{Z}_{70}\left(30 \%\right.$ AYB: $70 \%$ Corn) and $\mathrm{Z}_{100}$ (100\% Corn) porridges in terms of consistency was understandable as they contained more of corn which has coarse nature than the AYB. Porridges with more AYB were more acceptable taste-wise. General acceptability followed similar trend. Nout [29] reported that roasting of food imparted significant desirable quality on odour that corresponds to aroma development. Abdoulaye et al. [30] also included improvement of sensory qualities as one of the goals of roasting. Color and taste were two organoleptic properties that predicted acceptability of a food. All samples were acceptable to the panelists. This was not surprising as most people will accept a product that they can sensorial appreciate especially once there is indication of good health. The low scores of $\mathrm{Zc}_{100}$ (100\% fermented corn porridge) in terms of flavor and general acceptability was attributed to the reduced $\mathrm{pH}$, increased titratable acidity during fermentation [31], and the breakdown of complex carbohydrates to organic acids and other simpler substances [32] that imparted flavor and aroma to the gruel. It was also noted that the brown color of AYB flour resulting roasting according to Abdoulaye et al. [30] did not reduce its acceptability.

The microbial analysis shows that all the porridges contained viable organisms that were not part of the natural microfloral of AYB seeds. These included Lactobacillus jensenii, Bacillus coagulans, Acrococcus viridans, Canadidan mycoderm. Although Agboola [33] opined that the seeds of AYB had high aerobic count attributed to its high protein content. The TVC were more in samples $\mathrm{S}_{70} \mathrm{Z}_{30}(70 \%$ AYB: $30 \%$ Corn), $\mathrm{S}_{50} \mathrm{Z}_{50}\left(50 \%\right.$ AYB: $50 \%$ Corn), and $\mathrm{S}_{30} \mathrm{Z}_{70}(30 \%$ AYB: $70 \%$ Corn) than the other porridges. This could have been introduced during the processing and reconstitution of the flour blends. The coliforms were more in the porridges with higher quantity of corn than 
DOI: https://dx.doi.org/10.4314/jdan.v12i1.3

AYB. This may have been possible during oven drying of the corn with lower temperature for longer time that allowed some persistent microbes to thrive compared to the higher roasting temperature for short period used for drying AYB that formed a higher proportion of the other porridges. The FAO/WHO [34] revealed that roasting reduced micro-organisms and enzyme activity and destroyed insects to improve keeping qualities. It was comforting to note that microorganisms like E. coli, Salmonella, L. monocytogenes, Bacillus cereus, Clostridium botulinium and $C$. perfringens which were not expected in a food product were not isolated in the porridges. The porridges contained some bacteria (Staphylococcus aureus, Bacillus cereus, Micrococcus spp, Enterobacter aerogenes) that ranged from $1.2 \times 10^{1}$ to $2.0 \times 10^{2}$ $\mathrm{cfu} / \mathrm{g}$, and fungi (Pencillum spp. Rhizopus spp.) from $1.0 \times 10^{2}$ to $2.0 \times 10^{1} \mathrm{cfu} / \mathrm{g}$; but the values were within the acceptable limits $\left(10^{5} \mathrm{cfu} / \mathrm{g}\right)$ and recommendation for good manufacturing practice [13]. The lower ash content of this study porridges in relation to other study [18] may have contributed to their low microbial loads. There is evidence that flours with lower ash content have greater reductions in microbial population [35]. Staphylococcus spp. were the dominant bacteria isolated from the porridges (Table 6). This might be due to post-processing contamination. Staphylococcus aureus is known to be widely distributed on human skin, mouth, nose, hair and hands. The presence of Bacillus cereus might be due to the processing materials and storage temperature which favored the growth and proliferation of organisms. Consequently, thorough and proper heating of food before consumption is advocated. The absence of $E$. coli and other opportunistic human pathogens could be attributed to the high temperature involved in making of the porridges.

The fungal profile of the test porridges shows that samples 100\% AYB $\left(\mathrm{S}_{100}\right), 70 \%$ AYB: $30 \%$ Corn $\left(\mathrm{S}_{70} \mathrm{Z}_{30}\right), 50 \%$ AYB: $50 \%$ Corn $\left(\mathrm{S}_{50} \mathrm{Z}_{50}\right)$, and $30 \%$ AYB: $70 \%$ Corn $\left(S_{30} Z_{70}\right)$ were not contaminated with fungi. This indicated the use of good raw materials in processing these porridges. However, viable mold spores were present in the control and could be attributed to handling during milling and drying. Afolabi, Oloyede and Agbaje [36] reported high (5.0 x $10^{1}$ to $5.85 \times 10^{1} \mathrm{cfu} / \mathrm{g}$ ) fungal growth due to postharvest handling. The microbiological load of the porridges was significantly $\mathrm{p}<0.05$ lower $\left(1.2 \times 10^{1}\right.$ to $2.0 \times 10^{2} \mathrm{cfu} / \mathrm{g}$ ) and less varied (Staphylococcus aureus, Bacillus cereus, Micrococcus spp, Enterobacter aerogenes, Pencillum spp. Rhizopus spp.) than those (Staphylococcus aureus, Bacillus sphaericus, staphylococcus carnosus subsp utilis, staphylococcus saprophyticus subsp bovis, streptococcus australis, Edwardsiella ictaluri, Aspergillus niger, Fusarium spp, Mucor spp, Penicillium spp Aspergiluus flavus and Aspergillus fumigatus) isolated in the latter study [36]. The loads were equally lower than $1.80 \times 10^{2}$ to $4.8 \times 10^{5} \mathrm{cfu} / \mathrm{g}$ TVC, $1.2 \times 10^{2}$ to $5.0 \times 10^{3} \mathrm{cfu} / \mathrm{g}$ fungal count; $1.0 \mathrm{x}$ $10^{2}$ to $1.6 \times 10^{3} \mathrm{cfu} / \mathrm{g}$ bacteria count reported in the study of Yusuf, Ojo, Egwujeh and Ebiloma [37] and Madueke, Awe and Jonah [38] respectively. This maybe because the porridges under study were laboratory prepared samples that observe Hazard Analysis and Critical Control Points (HACCP) approach and good manufacturing practices while these other authors worked on ready to eat street foods made by different vendors.

\section{CONCLUSION}

This study on chemical composition, sensory and microbial attributes of porridges made from African yam bean and corn seeds flour blends shows that in addition to contributing high fiber compared with traditional corn porridge, the porridges have improved nutrient content, safe microbial load and consumer acceptability, and will add variety not only to diabetic meals but to daily meals for all as well.

\section{ACKNOWLEDGEMENT}

The authors acknowledged the dexterity of the Eurofins Scientific Inc. for chemical analysis of the samples, the enthusiasm of out-patient diabetic patients from University of Nigeria Teaching Hospital that formed the panelists, commitment of the kitchen staff of the Dietetic department and the statistical expertise of Dr. Bui from Department of Statistics University of Port Harcourt.

\section{Ethics approval:}

Permission for the study was obtained from the University of Nigeria Teaching Hospital's Ethical Committee and ethical clearance certificate (UNTH/CSA/329/vol. 5) was obtained.

\section{Informed Consent:}

Thirty diabetics purposively selected from the hospital's out-patient's clinic were fully informed of the purpose and procedures of the research and their personal consents obtained.

\section{Conflict of interest}

None

\section{Funding}

The study was funded by the corresponding author 


\section{Author Contribution}

The authors articulated the concept and design of the study. H.N. collected, analyzed, interpreted the data, and drafted the manuscript. E.K reviewed the manuscript. Both authors made contributions to improve the manuscript.

\section{Data and material availability}

The data and materials for this work are available

\section{REFERENCES}

1 Chan, M. Non-communicable disease: a growing challenge. Foodstep 2012; 87 [Internet] Available from http://www.tearfund.org/tilz 2019.

2 European Public Health and Agriculture Consortium. Position on the future of the Common Agricultural Policy (CAP) Towards a healthier, more sustainable CAP Diet-related noncommunicable diseases in Europe. 2012 Edition [Internet] Available from www.equitychannel.net 2019

3 Onyechi UA, Nwachi IC. The potential role of African yam bean (Sphenostylis stenocarpa) in modulating postprandial blood glucose level of normal health diabetic adults. J. Diet. Assoc. Nig., 2010; 1(1): 16-23.

4 Rauf-Shah T, Prasad K, Kumar P. Maize- A potential source of human nutrition and health: A review. Cogent Food and Agriculture. 2016; 2 (1): 1166995.

5 Oniang', R.K, Shiundu R, Maundu P, Johns T. Diversity, nutrition and food security: the case of African leafy vegetables in hunger and poverty: the role of biodiversity. In SB. Ravi, Hoeschezeledon, MS, Edition Report of an international consultation on the role of biodiversity in achieving the UN Millenium Development goal of freedom from hunger and poverty 2006.

6 Adewale D. African Yam Bean: A food security crop? [Internet] Available from http://www.r4dreview.org/exploiting-thediversity-of-african-yam.bean/ 2010.

7 Institute of Medicine. Dietary reference intakes for energy, carbohydrate, Fibre, fat, fatty acids, cholesterol, protein and amino Acids. Food and Nutrition Board, Institute of Medicine Washington DC: National Academy Press; 2002.

8 Association of Official Analytical Chemists. Official methods of analysis Eighteenth Edition Rev.3, Washington DC: Association of Official Analytical Chemists International; 2010.

9 Association of Official Analytical Chemists. Official methods of analysis: Determination of Dietary Fiber, Complete; Washington DC: Association of Official Analytical Chemists International; 2009;01
10 Association of Official Analytical Chemists International, Determination of Total Dietary Fibre - HPLC Washington DC: Association of Official Analytical Chemists International; 2011;25

11 Tiez T. Method of determining Anti-nutrients. Analytical Biochemistry USA; Saunders: 1977; $536-539$.

12 American Oil Chemists Society. Official Method of Analysis. American Oil Chemists Society. Arlington VA, USA 2010.

13 International Commission on Microbiological Specifications on Food [ICMSF] Micro-organism in foods 2009. [Internet] Available from http://www.icmsf.lit.tar. 2017.

14 Mensah PD, Yeboah-manu K, Owusu-Darko D, Ablordey I. Street foods in Accra, Ghana: How safe are they? Bulletin of World Health Organization, 2002; 80: 546-554.

15 Adegunwa MO, Alama EO, Bakare HA, Godwin RO. Effect of fermentation length and varieties on the qualities of corn starch (ogi) production. Am. J. Food Nutr. 2011;12: 2157 - 2158.

16 Chandra S, Singh S, Kumari D. Evaluation of functional Properties and Sensory attributes of composite flours Biscuits. J. Food Sci. Tech. 2015; 52(6): 3681 - 3688

17 Aguilera Y, Martı'n-Cabrejas M A, Benı'tez V, Molla' E, Lo'pez-Andre'u FJ, Esteban R M. Changes in Carbohydrate fraction during dehydration process of common legumes. J. Food Composition and Analysis. 2009; 22: 678-683.

18 Pelgrom PJM, Boom RM, Schutyser MAI. Method development to increase protein enrichment during dry fractionation of starchrich legumes. Food and Bioprocess Technology 2015. [Internet] Available from http://dx.doi.org/10.1007/s11947-015-1513-0 2017.

19 Obse F, Geremew B, Sirawdink FF, Malhewos T. Nutritional quality and sensory acceptability of complementary food blended from maize (Zea mays) roasted pea (Pisum sativum), and malted barley (Hordium vulgare) Food Sci. Nutr. 2017; 5(2):173 -181.

20 Laxmi G, Chaturvedi N, Richa S. The impact of malting on nutritional composition of foxtail millet, wheat and chickpea. J. Nutr. Food. Sci. 2015; 5 (5): 1000407.

21 Osundahunsi O F, Aworh OC. Nutritional evaluation, with emphasis on protein quality of maize-based complementary foods enriched with soya bean \& cowpea tempe. Int. J. Food Sci. Tech. 2003; 38: 809-813. 
DOI: https://dx.doi.org/10.4314/jdan.v12i1.3

22 Oghbaei M, Prakash J. Effect of fractional milling of wheat on nutritional quality of milled fractions. Trends Carbohydrate Research. 2013; 5: 53-58.

23 Ejoh AR, Tanya AN, Djuikwo NA, Mbofung CM. Effect of processing and preservation methods on vitamin $\mathrm{C}$ and total carotenoid levels of some Veronia (bitter leaf) species. African Journal of Food Agriculture, Nutrition and Development. 2005; 5(2): 105-117.

24 Fardet A. New hypotheses for the healthprotective mechanisms of whole-grain cereal: what is beyond fiber? Nutrition Research Reviews. 2010; 23: 65-134.

25 Gupta RK, Gangoliya SS, Singh NK. Reduction of phytic acid and enhancement of bioavailable micronutrients in food grains. J. Food. Sci. Tech. 2015; 52: 676-684.

26 Onyeke EN, Omubo TT. Effect of heat treatment on the proximate composition, energy values, and levels of some toxicants in African yam bean (Sphenostylis stenocarpa) seed varieties. Plants Foods for Human Nutrition. 2002; 57 (3-4): 223231

27 Xu B, Chang SKC. Effect of soaking, boiling, and steaming on total phenolic content and antioxidant activities of cool season food legumes. Food Chemistry. 2008; 110: 1-13.

28 Miller G, Prakash A, Decker E. Whole-grain micronutrients: In L. Marquart, J L. Slavin RG. Fulcher (Eds.), Whole-Grain Foods in Health and Disease. St Paul, MN: Eagan Press; 2002.

29 Nout MJR. Processed weaning foods for tropical climates. Int. J. Food Sci. 1993; 43: 213 -221.

30 Abdoulaye C, Brou K, Jie C. Phytic Acid in Cereal Grains: Structure, Healthy or Harmful ways to reduce phytic acid in cereal grains and their effects on nutritional quality. American
Journal of Plant Nutrition and Fertilization Technology. 2011; 1(1): $1-22$.

31 Akinyele TO. Effects of traditional methods of processing on the nutrient component and some anti-nutritional factors in cowpea (Vigna unguiculata). Food Chemistry. 1989; 33: 291299.

32 Babajide JM, Babajide SU, Uzochukwu, SVA. Cassava soy weaning food. Biological evaluation and effects on rat organs. Plant Food for Human Nutrition. 2001; 56: 167-173.

33 Jeff-Agboola, Y.A. Microorganisms associated with natural fermentation of African yam bean (Sphenostylis stenocarpa) seeds for the production of Otiru. Research Journal of Microbiology. 2007; 2: 816-823.

34 Food and Agriculture Organization/World Health Organization (FAO/WHO) Food safety: What you should know. World Health Organization South-East Asia World Health Day 2015 WHO South-East Asia.

35 Ardent Flour Mills. Flour food safety. Ardent Mills Safeguard [Internet] Available from www.http//ardent_flour_mills_food_safety_whit e_paper.pdf. 2017

36 Afolabi OR, Oloyede AR, Agbaje M. Microbiological Safety of corn-based snack products Audun Sold in Abeokuta, SouthWestern Nigeria. Nig. Food J. 2011; 29(1): 36-40.

37 Yusuf PA, Opejga JL, Aka OM. Effect of partial replacement of wheat with peanut flour on the chemical, sensory and microbial quality of bread. Nig. J. Nutr. Sci. 2016; 37 (1): 72-77

38 Madueke SN, Awe S, Jonah, AI. Microbiological analysis of street foods along Abuja express way, Lokoja. American Journal of Research Communication. 2014; 2 (1), 196 -211. 